INTERNATIONAL JOURNAL OF RESEARCHES IN BIOSCIENCES, AGRICULTURE \& TECHNOLOGY (C) VISHWASHANTI MULTIPURPOSE SOCIETY (Global Peace Multipurpose Society) R. No. MH-659/13(N) www.vmsindia.org

\title{
ANALYSIS OF WATER QUALITY USING PHYSICO-CHEMICAL PARAMETERS \\ OF VIJASAN LAKE IN BHADRAWATI, DIST - CHANDRAPUR, MAHARASHTRA, INDIA
}

\author{
Nasare P. N. \\ Nilkanthrao Shinde Science and Arts College, Bhadrawati, Chandrapur (M.S) India \\ Email: pnnasare@rediffmail.com
}

\begin{abstract}
This paper present to study of physico-chemical parameters of Vijasan Lake in Bhadrawat, Dist- Chandrapur, Maharashtra, India. Monthly changes in physical and chemical parameters such as Atmospheric Temperature, Water Temperature, Colour, Odour, Taste, Turbidity, Transparency, Conductivity, T.S., TDS, T.S.S., and pH, DO, BOD, COD, Alkalinity, Total hardness, Calcium, Magnesium, Chloride, Sulphate were analyzed for a periods of December 2016, January 2017, February 2017. All parameters were not within permissible limits. The result indicates that the Lake is highly polluted with different harmful contaminants.
\end{abstract}

Keywords:- Vijasan lake, Physico-chemical parameters, Monthly variation

\section{Introduction:}

Water is one of the most important component of the ecosystem. Better quality of water described by its physical, chemical and biological characterstics. But some correlation was possible among these parameters and the significant one would be useful to indicate quality of water.

Due to increased human population, industrialization, use of fertilizers in agriculture and man-made activities. The natural aquatic resources are causing heavy and varied pollution in aquatic environment leading to water quality and depletion of aquatic biota.

In the present study involves the analysis of water quality in terms of physico-chemical parameters of Vijasan lake Bhadrawati, Dist-Chandrapur, Maharashtra, India. It is located in $20^{\circ} 10^{\mathrm{I}}$ 04.870 $\mathrm{N}$ Latitude and $79^{\circ} 07^{\mathrm{I}}$ 49.94I $\mathrm{E}$ Longitude. The area of Vijasan Lake is 20.72 hectares. The height of Bhadrawati at sea level is 549 meter. The Vijasan Lake is basically used for shingada cultivation, and fisheries activities by Dhiwar community in india. Still now several researchers have carried out study on physico-chemical and biological characteristics of standing and running water resources (Pandey et al 1993, Trivedy \& Goel (1986), Kodarkar, 1992)

\section{Materials and Methods:}

The water samples from Vijasan Lake were collected from five different sample sites (V1 V2 V3 V4 V5) in the morning hours between 9 to 11 am in Bisleri bottles regularly for every month. The water samples were immediately brought into laboratory for the estimation of various physico-chemical parameters like. Water temperate, transparency and $\mathrm{pH}$ were recorded at the time of sample collection, by using thermometer and pocket digital $\mathrm{pH}$ meter. Transparency was measured with the help of Secchi Disc while other parameters such as other physico-chemical parameters were estimated by using standard methods as presented by APHA, AWW (1985), Trivedy and Goel (1986) \& Kodarkar (1992).

\section{Result and Discussion:}

Monthly variation in physic-chemical parameter is presented in table - 1,2,3.

\section{Physical Parameters -}

1. Atmospheric temperature - In December 2016, atmospheric temperature ranges from $17-18^{\circ} \mathrm{C}$, In January - 2017, it was $18-19^{\circ} \mathrm{C}$ and in February 2017 , it was 20-2 $1^{\circ} \mathrm{C}$. Atmospheric temperature was found maximum in February - 2017 and minimum in December - 2016.

2. Water temperature - In December 2016, water temperature ranges from 14$15^{\circ} \mathrm{C}$, In January - 2017, it was $16-17^{\circ} \mathrm{C}$ and in February 2017, it was $19-20^{\circ} \mathrm{C}$. Water temperature was found maximum in February-2017and minimum in December 2016. 
3. Colour - Colour was observed visually and colour was found brownish in all three months due to heavy contamination.

4. Odour - The odour was disagreeable odour in water may be because of presence of decaying vegetation, inorganic constituents, organic substances discharge of waste water in water bodies.

5. Taste :- Water was found bitter during December - 2016, January - 2017 and February - 2017.

6. Turbidity - The turbidity of water fluctuates during December - 2016 and ranges from 112-112.8 NTU, in January 2017, it was 112.2-112.32 NTU and in February - 2017, it was 112-112.8 NTU respectively the maximum values were recorded in December - 2016 and in February-2017. It might be due to human activities, decrease in the water level and presence of suspended particulate matter.

7. Transparency - Transparency values were ranged from $24-24 \mathrm{~cm}$ in December 2016, 24-28 cm in January-2017 and 24-27 cm in February-2017.

8. Conductivity - The conductivity values were ranged from $331-649 \mathrm{mho} / \mathrm{cm}$ in December-2016, in January-2017, it was 330-595 mho/cm, in February-2017, it was 332-650 mho/cm respectively. The maximum values were found in February 2017.

9. Total solids (T.S.) - T. S. was ranged from 988-992 $\mathrm{mg} / 1$ in December- 2016, 986-995 mg/ml in January -2017 and 988$995 \mathrm{mg} / \mathrm{ml}$ in February-2017 respectively.

10. Total dissolved solids (TDS) - The total dissolved solids fluctuates from during three months. In December-2016, it was found between 992-998 mg/L. In January -2017, it was $993-998 \mathrm{mg} / \mathrm{L}$. In February-2017, it was found $992-995 \mathrm{mg} / \mathrm{L}$.

11. Total suspended Solids (TSS) - The values of total suspended solids ranged from 2.784-6.022 $\mathrm{mg} / \mathrm{L}$ in December-2016, in January-2017, it was 2.781-6.021 mg/L and in February-2017, it was 2.78-6.022 $\mathrm{mg} / \mathrm{L}$.

12. $\mathbf{P H}^{\mathrm{H}}$ - $\mathrm{PH}$ was ranged from $5.71-6$ in December -2016, in January-2017, it was ranged from 5.63-6.02 and in February2017 , it was ranged from 5.7-6. The $\mathrm{PH}^{\mathrm{H}}$ was acidic and maximum $\mathrm{PH}^{\mathrm{H}}$ value was 6 and minimum was 5.63. The factors like our temperature bring about changes in the $\mathrm{PH}$ of water bio-chemical and chemical reactions are influenced by the $\mathrm{PH}^{\mathrm{H}}$. The values were minimum in winter season.

13. Dissolved Oxygen (DO)- The values of DO ranged from $208-3.5 \mathrm{mg} / \mathrm{L}$ in December-2016. In January -2017, it was ranged from $2.7-3.7 \mathrm{mg} / \mathrm{L}$ and in February2017 , it was ranged from $2.7-3.7 \mathrm{mg} / \mathrm{L}$.

14. Biological oxygen Demand (BOD) :Tin December -2016, BOD value were ranged from $3.968-4.891 \mathrm{mg} / \mathrm{L}$. In January -2017 , it was ranged from $3.75-5.112 \mathrm{mg} / 1$ and it was ranged from 3.97-5.11 mg/1 in February -2017. Biological oxygen demand measures the amount of oxygen that microorganism consume, while decomposing organic matter. BOD is amount of dissolved oxygen requires for the biochemical decomposition of certain inorganic materials (e.g. iron, sulphates). Vijasn Lake has high organic and inorganic waste material and recorded maximum value in winter season.

15. Chemical Oxygen Demand (COD) :The COD values ranged from 12.1 to 14.1 $\mathrm{mg} / 1$ in December -2016, it was ranged from 13.2 - 14.1 in January -2017 and in February-2017, it was ranged from 13.1-14 $\mathrm{mg} / 1$. Maximum values were recorded in winter season.

16. Alkalinity :- Alkalinity is a chemical measurement of waters ability to neutralize acids. The values were ranged from 500$525 \mathrm{mg} / 1$. In January -2017 and in February-2017, it was ranged from 535$995 \mathrm{mg} / 1$. The values are maximum in winter season and it indicates the presence of bicarbonates, carbonates and hydroxide. The values above the normal level water taste becomes, unpleasant. High alkalinity of water affects the health.

17. Total Hardness (TH) :- Total Hardness in defined as the sum of calcium and magnesium hardness in $\mathrm{mg} / 1$, as $\mathrm{CaCO}_{3}$. The values ranged from 195-215 mg/1 in December-2016. In January-2017, Values were ranged from $195-219 \mathrm{mg} / 1$ and in February -2017, values were ranged from 195-219 mg/1. The maximum values of Total Hardness were recorded in winter season. 
18. Calcium :- Calcium generally has the highest concentration and minerals constitute the primary sources of calcium ion in waters. Calcium is present in water as a consequence of equilibrium between calcium and magnesium carbonate minerals of $\mathrm{CO}_{2}$ dissolved in water surface water containing a high level of carbon-dioxide readily dissolved calcium from its carbonate minerals. The content of calcium in drinking and surface water is not regulated. The valued ranged from 210.42-221.4 mg/1 in December-2016. In January 2017, values were ranged from $210.42-226.3 \mathrm{mg} / 1$ and in February 2017, the values were ranged from 210-226 mg/1. The maximum values were recorded in winter season.

19. Magnesium - Magnesium is also one of the important mineral for various enzymatic transformations. In December 2016, the values were ranged from $11.36-13.4 \mathrm{mg} / 1$. In January 2017, the values were ranged from $11.2-13.42 \mathrm{mg} / 1$ and the values were ranged from 11.2-13.5 mg/1. Maximum values were recorded in winter.

20. Chloride:- The ionized form of chloride is one of the most abundant inorganic ions, natural and waste water. In December2016, the values were ranged from 99.4$120.7 \mathrm{mg} / 1$. In January 2017, the values were ranged from 99.9-115.5 mg/1. and in February 2017, it was ranged from 99.9$115.5 \mathrm{mg} / 1$.

21. Sulphate :- Natural water contains sulphate ions and of these ions are also soluble in water. In December-2016, the values were ranged from 11.08-11.45 mg/1. In January -2017 , the values were ranged from 11.01-12.1 mg/1 and in February 2017, the values were ranged from 11-12.5 $\mathrm{mg} / 1$.

\section{Conclusion:}

In the study, the values of physico-chemical parameters obtained from each point were different the values obtained were compared with the ICMR standards. The values are not permissible with ICMR standards.

\section{Acknowledgements:}

The author is grateful to Dr. L. S. Ladke, Principal, Nilkanthrao Shinde Science and Arts College, Bhadrawati for providing all possible facilities during the study of physico-chemical properties of Vijasan Lake. Author also thanks to Mr. N. Y. Shinde (ExMLA), Secretary, Bhadrawati Shikshan Sanstha, Bhadrawati for his support and co-operation.

\section{Reference :}

Pandey, A. K., Siddhiqui, S. Z. and Rama Rao (1993) Physico-chemical and biological characteristics of Husain sagar, an industrially polluted lake, Hyderabad. Proc. Acad. Environ. Biol. 2(2), 161-167.

Trivedy, R. K. and Goel, P. K. (1986) Chemical and biological methods for water pollution studies, Environmental publication, Karad, Maharashtra.

Kodarkar, M. S. (1992) - Methodology for water analysis, Physico-chemical, Biological and Microbiological Indian Association of Aquatic Biologists, Hyderabad, Publication 2, PP50.

A PHA (1985) - Standard Methods for Examination of water and waste water, $20^{\text {th }}$ edition, American Public Health Association, Washington DC. 
Table-1.: Physico-Chemical parameters opf Vijasan Lake, Bhadrawati, site - V1 V2 V3 V4 V5 during December -2016.

\begin{tabular}{|c|c|c|c|c|c|c|c|c|}
\hline \multicolumn{9}{|c|}{ Month \& Year December - 2016} \\
\hline \multicolumn{9}{|c|}{ PHYSICAL PARMETERS } \\
\hline PARAMETER & Unit & V1 & V2 & V3 & V4 & V5 & Mean & $\begin{array}{l}\text { BIS, IS : } 10500 \\
\text { (1983) ICMR } \\
\text { standard }\end{array}$ \\
\hline $\begin{array}{l}\text { Atmospheric } \\
\text { Temperature }\end{array}$ & $\left(\mathrm{O}^{0} \mathrm{C}\right)$ & 17 & 17 & 18 & 17 & 18 & 17.4 & - \\
\hline $\begin{array}{l}\text { Water } \\
\text { Temperature }\end{array}$ & $\left(\mathrm{O}^{0} \mathrm{C}\right)$ & 15 & 14 & 15 & 15 & 14 & 14.6 & - \\
\hline Colour & - & 360 & 300 & 200 & 180 & 100 & 228 & 10 \\
\hline Odour & - & 1.82 & 1.72 & 1.8 & 1.9 & 1.78 & 1.804 & Unobjectionable \\
\hline Tastes & - & 1.8 & 1.92 & 1.86 & 1.78 & 1.82 & 1.836 & - \\
\hline Turbidity & (NUT) & 112.32 & 112.8 & 112.32 & 112 & 112.64 & 112.416 & 10 (Max.) \\
\hline Transparency & $(\mathrm{cm})$ & 25 & 24 & 27 & 25 & 25 & 25.2 & - \\
\hline Conductivity & (mhos $/ \mathrm{cm})$ & 241 & 249 & 649 & 419 & 331 & 377.8 & - \\
\hline T.S. & $(\mathrm{mg} / \mathrm{l})$ & 992 & 988 & 988 & 990 & 996 & 990.8 & - \\
\hline T.D.S. & $(\mathrm{mg} / \mathrm{l})$ & 994 & 996 & 998 & 992 & 992 & 994.4 & - \\
\hline T.S.S. & $(\mathrm{mg} / \mathrm{l})$ & 5.866 & 5.668 & 2.784 & 6.022 & 2.809 & 4.6296 & - \\
\hline \multicolumn{9}{|c|}{ CHEMICAL PARAMETERS } \\
\hline PARAMETER & Unit & V1 & V2 & V3 & V4 & V5 & Mean & $\begin{array}{l}\text { BIS, IS : } 10500 \\
\text { (1983) ICMR } \\
\text { standard }\end{array}$ \\
\hline $\mathrm{P}^{\mathrm{H}}$ & $(\mathrm{mg} / \mathrm{l})$ & 5.75 & 5.96 & 5.64 & 6 & 5.71 & 5.812 & $6.5-8.5$ \\
\hline $\mathrm{DO}$ & $(\mathrm{mg} / \mathrm{l})$ & 3.4 & 3.2 & 2.8 & 3.2 & 3.5 & 3.22 & - \\
\hline $\mathrm{BOD}$ & $(\mathrm{mg} / \mathrm{l})$ & 4.891 & 4.792 & 3.968 & 4.114 & 4.334 & 4.4198 & - \\
\hline COD & $(\mathrm{mg} / \mathrm{l})$ & 13.7 & 13.2 & 12.1 & 14.1 & 13.2 & 13.26 & - \\
\hline Alkalinity & $(\mathrm{mg} / \mathrm{l})$ & 495 & 500 & 545 & 545 & 525 & 522 & - \\
\hline Total Hardness & $(\mathrm{mg} / \mathrm{l})$ & 190 & 200 & 210 & 220 & 218 & 207.6 & 300 \\
\hline Calcium & $(\mathrm{mg} / \mathrm{l})$ & 210.42 & 216.4 & 221.4 & 218.4 & 220.4 & 179.607 & 75 \\
\hline Magnesium & $(\mathrm{mg} / \mathrm{l})$ & 12.31 & 12.37 & 13.4 & 11.36 & 11.71 & 12.63 & 0.1 (Max.) \\
\hline Chloride & $(\mathrm{mg} / \mathrm{l})$ & 99.4 & 112.18 & 113.6 & 112.18 & 120.7 & 11.612 & 250 \\
\hline Sulphate & $(\mathrm{mg} / \mathrm{l})$ & 11.09 & 11.12 & 11.25 & 11.45 & 12.35 & 11.452 & 150 \\
\hline
\end{tabular}

Table -2: Physico-chemical parameters of Vijasan Lake, Bhadrawati, site - V1 V2 V3 V4 V5 during January -2017.

\begin{tabular}{|c|c|c|c|c|c|c|c|c|}
\hline \multicolumn{9}{|c|}{ Month \& Year - January - 2017} \\
\hline \multicolumn{9}{|c|}{ PHYSICAL PARMETERS } \\
\hline PARAMETER & Unit & V1 & V2 & V3 & V4 & V5 & Mean & $\begin{array}{l}\text { BIS, IS : } 10500 \\
\text { (1983) ICMR } \\
\text { standard }\end{array}$ \\
\hline $\begin{array}{l}\text { Atmospheric } \\
\text { Temperature }\end{array}$ & $\left(\mathrm{O}^{0} \mathrm{C}\right)$ & 19 & 18 & 19 & 19 & 18 & 18.6 & - \\
\hline $\begin{array}{l}\text { Water } \\
\text { Temperature }\end{array}$ & $\left(\mathrm{O}^{0} \mathrm{C}\right)$ & 17 & 17 & 16 & 17 & 17 & 16.8 & - \\
\hline Colour & - & 300 & 290 & 200 & 200 & 190 & 236 & 10 \\
\hline Odour & - & 1.95 & 1.76 & 1.78 & 1.9 & 1.7 & 1.818 & Unobjectionable \\
\hline Tastes & - & 1.9 & 1.85 & 1.9 & 1.82 & 1.82 & 1.858 & - \\
\hline Turbidity & (NUT) & 112.21 & 112.25 & 112.45 & 112.2 & 112.32 & 112.286 & 10 (Max.) \\
\hline Transparency & $(\mathrm{cm})$ & 26 & 24 & 28 & 25 & 26 & 25.8 & - \\
\hline Conductivity & $(\mathrm{mhos} / \mathrm{cm})$ & 245 & 255 & 595 & 485 & 330 & 382 & - \\
\hline T.S. & $(\mathrm{mg} / \mathrm{l})$ & 990 & 987 & 986 & 991 & 995 & 987.8 & - \\
\hline T.D.S. & $(\mathrm{mg} / \mathrm{l})$ & 995 & 997 & 998 & 993 & 993 & 986.2 & - \\
\hline T.S.S. & $(\mathrm{mg} / \mathrm{l})$ & 5.855 & 5.665 & 2.781 & 6.021 & 2.905 & 4.6456 & - \\
\hline \multicolumn{9}{|c|}{ CHEMICAL PARAMETERS } \\
\hline PARAMETER & Unit & V1 & V2 & V3 & V4 & V5 & Mean & $\begin{array}{l}\text { BIS, IS : } 10500 \\
\text { (1983) ICMR } \\
\text { standard }\end{array}$ \\
\hline $\mathrm{P}^{\mathrm{H}}$ & $(\mathrm{mg} / \mathrm{l})$ & 5.71 & 5.95 & 5.63 & 6.02 & 5.69 & 5.8 & $6.5-8.5$ \\
\hline $\mathrm{DO}$ & $(\mathrm{mg} / \mathrm{l})$ & 2.9 & 3.4 & 2.7 & 3.5 & 3.7 & 3.24 & - \\
\hline BOD & $(\mathrm{mg} / \mathrm{l})$ & 5.112 & 4.891 & 3.995 & 3.75 & 3.85 & 4.3196 & - \\
\hline COD & $(\mathrm{mg} / \mathrm{l})$ & 13.5 & 13.2 & 14.1 & 13.2 & 13.5 & 13.5 & - \\
\hline Alkalinity & $(\mathrm{mg} / \mathrm{l})$ & 545 & 545 & 495 & 535 & 527 & 529.4 & - \\
\hline Total Hardness & $(\mathrm{mg} / \mathrm{l})$ & 195 & 205 & 211 & 211 & 215 & 207.4 & 300 \\
\hline Calcium & $(\mathrm{mg} / \mathrm{l})$ & 210.4 & 219.3 & 226.3 & 218.4 & 220.3 & 218.34 & 75 \\
\hline Magnesium & $(\mathrm{mg} / \mathrm{l})$ & 12.11 & 12.35 & 13.42 & 11.33 & 11.2 & 12.082 & 0.1 (Max.) \\
\hline Chloride & $(\mathrm{mg} / \mathrm{l})$ & 99.9 & 112.15 & 113.5 & 112.16 & 115.6 & 110.642 & 250 \\
\hline Sulphate & $(\mathrm{mg} / \mathrm{l})$ & 11.01 & 11.08 & 11.2 & 11.35 & 12.2 & 11.368 & 150 \\
\hline
\end{tabular}


Table -3: Physico-chemical parameters of Vijasan Lake, Bhadrawati, site - V1 V2 V3 V4 V5 during February - 2017.

\begin{tabular}{|c|c|c|c|c|c|c|c|c|}
\hline \multicolumn{9}{|c|}{ Month \& YearFebruary - 2016} \\
\hline \multicolumn{9}{|c|}{ PHYSICAL PARMETERS } \\
\hline PARAMETER & Unit & V1 & V2 & V3 & V4 & V5 & Mean & $\begin{array}{l}\text { BIS, IS : } 10500 \\
\text { (1983) ICMR } \\
\text { standard }\end{array}$ \\
\hline $\begin{array}{l}\text { Atmospheric } \\
\text { Temperature }\end{array}$ & $\left(\mathrm{O}^{0} \mathrm{C}\right)$ & 21 & 20 & 21 & 21 & 20 & 20.6 & - \\
\hline Water Temperature & $\left(\mathrm{O}^{0} \mathrm{C}\right)$ & 20 & 20 & 20 & 19 & 20 & 19.8 & - \\
\hline Colour & - & 300 & 300 & 250 & 180 & 100 & 226 & 10 \\
\hline Odour & - & 1.82 & 1.95 & 1.9 & 1.78 & 1.76 & 1.842 & Unobjectionable \\
\hline Tastes & - & 1.9 & 1.82 & 1.78 & 1.9 & 1.78 & 1.842 & - \\
\hline Turbidity & (NUT) & 112 & 122 & 112 & 112.8 & 112.5 & 112.378 & 10 (Max.) \\
\hline Transparency & $(\mathrm{cm})$ & 25 & 24 & 27 & 25 & 24 & 25 & - \\
\hline Conductivity & (mhos $/ \mathrm{cm})$ & 249 & 241 & 650 & 420 & 332 & 378.4 & - \\
\hline T.S. & $(\mathrm{mg} / \mathrm{l})$ & 991 & 990 & 988 & 991 & 995 & 991 & - \\
\hline T.D.S. & $(\mathrm{mg} / \mathrm{l})$ & 995 & 994 & 992 & 995 & 994 & 994 & - \\
\hline T.S.S. & $(\mathrm{mg} / \mathrm{l})$ & 5.85 & 5.67 & 2.78 & 6.022 & 2.902 & 4.6442 & - \\
\hline \multicolumn{9}{|c|}{ CHEMICAL PARAMETERS } \\
\hline PARAMETER & Unit & V1 & V2 & V3 & V4 & V5 & Mean & $\begin{array}{l}\text { BIS, IS : } 10500 \\
\text { (1983) ICMR } \\
\text { standard }\end{array}$ \\
\hline $\mathrm{P}^{\mathrm{H}}$ & $(\mathrm{mg} / \mathrm{l})$ & 5.75 & 5.95 & 5.7 & 6 & 5.7 & 5.82 & $6.5-8.5$ \\
\hline $\mathrm{DO}$ & $(\mathrm{mg} / \mathrm{l})$ & 3.1 & 3.4 & 2.7 & 3.5 & 3.7 & 3.28 & - \\
\hline BOD & $(\mathrm{mg} / \mathrm{l})$ & 4.99 & 5.11 & 3.97 & 4.199 & 4.335 & 4.5206 & - \\
\hline COD & $(\mathrm{mg} / \mathrm{l})$ & 13.8 & 13.5 & 14. & 13.1 & 13.5 & 13.58 & - \\
\hline Alkalinity & $(\mathrm{mg} / \mathrm{l})$ & 995 & 545 & 535 & 545 & 535 & 631 & - \\
\hline Total Hardness & $(\mathrm{mg} / \mathrm{l})$ & 195 & 205 & 210 & 219 & 215 & 208.8 & 300 \\
\hline Calcium & $(\mathrm{mg} / \mathrm{l})$ & 210 & 216 & 226 & 218.4 & 220.4 & 218.406 & 75 \\
\hline Magnesium & $(\mathrm{mg} / \mathrm{l})$ & 12.3 & 12.4 & 13.5 & 11.36 & 11.2 & 12.146 & 0.1 (Max.) \\
\hline Chloride & $(\mathrm{mg} / \mathrm{l})$ & 99.9 & 112 & 114 & 112.2 & 115.2 & 110.654 & 250 \\
\hline Sulphate & $(\mathrm{mg} / \mathrm{l})$ & 11 & 11.5 & 11.1 & 11.3 & 12.5 & 11.48 & 150 \\
\hline
\end{tabular}

